\title{
BİR BAĞLILIK PRATİĞİ OLARAK ÖRGÜTSEL SESSİZLIK
}

\author{
Yrd. Doç. Dr. Gaye ATILLLA GÖK*
}

\begin{abstract}
ÖZ
İletişim ihtiyacının sürekli artması ve susma gereksinimi paradoksal bir yapı olarak karşımızdadır. Sessizlik, problemler ya da konular karşısında konuşmanın faydasız velveya tehlikeli olduğuna dair örgütte çalışanlar arasında yaygın olarak paylaşılan algıları ifade eder. Bu, merkezine insan'ı alan yeni yönetim paradigmaları ile de örtüşmemektedir. Çalışanların örgütlerine karşı geliştirdikleri bağlllık duygularının, örgütsel sessizliği de beraberinde getirmesi ise son yılların konularındandır. Bu çalışmada çalışanların örgütsel bağlllık ve örgütsel sessizlik boyutlarının belirlenerek aralarındaki ilişkinin ortaya çıkartılması ve bağlılık boyutlarının örgütsel sessizlik üzerindeki etkisinin saptanması amaçlanmıştır. Çalışmanın amacına ulaşmak için İzmir Güzelyalı Hava Lisan okulunda uygulanan 277 ankete faktör, korelasyon ve çoklu regresyon analizleri uygulanmıştır. Elde edilen bulgulara göre özellikle devam bă̆gllı̆̆ının ilişkisel ve kabullenici sessizliği kuvvetli bir şekilde ve pozitif yönde etkilediği; duygusal ve devam bağlılı̆̆ının savunmacı sessizliği kuvvetli bir şekilde ve negatif yönde etkilediği belirlenmiștir. Ayrıca normatif bă̆lllı̆̆ın savunmacı sessizlik üzerinde anlamlı bir etkisinin olmadı̆̆ı ortaya çıkmıştır.
\end{abstract}

Anahtar Kelimeler: Örgütsel Bağlllık, Örgütsel Sessizlik, Regresyon.

Jel Sinıflandırması: M10, M12, D23

\section{ORGANIZATIONAL SILENCE as a PRACTISE of COMMITMENT ABSTRACT}

Consistent increase in communication necessity and 'need' for silence forms a paradoxical structure. Silence refers to the widely shared perception among employees that it is useless and/or dangerous to speak up in face of problems or issues. The Organizational Silence, derived from employees' sense of commitment to the organization, is one of the widely discussed issues in recent years. The aim of this study is to determine dimensions of organizational commitment and organizational silence of the employees' to reveal the relationship between these notions, and thus to define the effect of organizational commitment on organizational silence. In order to achieve this goal; factor, correlation and multiple regression analysis is applied to the conducted survey of 277 employees working at Izmir Guzelyalı Air Force Language School. According to the empirical evidence from the survey; continuance commitment, particularly, has a moderate positive effect on pro-social and

\footnotetext{
*Süleyman Demirel Üniversitesi, İktisadi ve İdari Bilimler Fakültesi, İşletme Bölümü. gayeagok@gmail.com
} 
acquiescent silence; affective and continuance commitment has a moderate negative effect on defensive silence. Another output of the survey is normative commitment has no significant effect on defensive silence.

Key Words: Organizational Commitment, Organizational Silence, Regression.

Jel Classification: M10, M12, D23

\section{GİRIȘ}

Modern sosyal psikolojide kitle konusundaki görüşler temel olarak iki düşünce geleneğinden beslenmektedir: Biri, kökleri Le Bon'a kadar geri giden 'grup zihni' geleneği ve diğeri Allport'un öncülük ettiği 'bireyselci psikoloji' geleneğidir (Kayaoğlu, 2003: 207). Örgütsel bağl1lık ve örgütsel sessizlik konularına bireysel değil grup zihni penceresinden bakılmalıdır. Bu da sade ve öz bir anlatımla, 'birey örgüte girdikten sonra örgütün üyesidir' demektir. Buna bireysellik yitimi denir. Le Bon, bireysellik yitimini toplumsal bulaşmanın nedenlerinden biri olarak kabul eder. Kalabalık içerisinde davranışa ilişkin hissedilen sorumluluğun azalması, kalabalık büyüdükçe histerinin de orantılı olarak büyümesi diğer nedenlerdendir. Le Bon (1997: 23)'a göre; kitleyi meydana getiren bireyler kimler olursa olsun; yaşama biçimleri, işgüçleri, karakterleri yahut zekâları ister benzer, ister ayrı olsun, kalabalık haline gelmiş olmaları onlara bir nevi kollektif ruh aşılar; bu ruh onları, herbiri tek başına, ayrı ayrı bulundukları halde hissedeceklerinden, düşüneceklerinden ve yapacaklarından tamamiyle başka hissettirir, düşündürür ve yaptırır. Gerçi Le Bon bu kavramı öncelikle normal dış1 (şiddet, linç..vb.) davranışları açıklamak için kullansa da 'birey'-'kitle içindeki birey' farkının vurgulanabilmesi için çıkış noktası kabul edilebilir. Buradaki kitle -zaten hali hazırda 'paylaşılan' kültürü olan- örgüt, bulaşan davranış da sessizlik davranışıdır. Bağlılık davranışının da -duygusal içeriğinden dolayı- 'bulaşıcı' olması muhtemeldir ve apayrı bir araştırma konusu olacak kadar zengindir.

\section{2. ÖRGÜTSEL BAĞLILIK KAVRAMI}

Bağlılık, sözlük (TDK, 2015) karşılığındaki gibi hem 'a. Bağlı olma durumu' hem de 'b. Birine karşı, sevgi, saygı ile yakınlık duyma ve gösterme, sadakat' anlamlarınını barındırmaktadır. Örgütsel bağlılık bireyin örgütüne ilişkin tutum ve davranışlarının anlaşılması bakımından çok önemli bir kavramdır (Altın Gülova ve Demirsoy, 2012: 56). Örgütlerin yaşamlarını sürdürebilmeleri için öncesinde işin niteliğine uygun seçilmiş ve örgütün amaçları doğrultusunda motive olmuş insan kaynağına sahip olmaları sonrasında ise bu insan kaynağının örgütte kalmasına ihtiyacı vardır. $\mathrm{Bu}$ ihtiyaç, örgütsel bağl1lıktır.

Bağlllık, bireyin işine yönelik tutumu ya da uyumu, bireyin kimliğinin işi ile bütünleşmesi ya da bağlantılı olmasıdır (Chusmir, 1982: 596). Sheldon (1971: 143) örgütsel bağl1lığ1, çalışanların kimliklerini örgütle özdeşleştirdikleri ve örgüte yönelik tutum ve yönelişler olarak tanımlamaktadır. 
Bağl1lık, kişilere göre farklı düzeylerde farklı şekillerde olabilir. Örgüte tam anlamıyla bağlanan bir işgörenin kendi değer ve inançları örgütün değer ve inançlarıyla uyuşmuş demektir (Usta ve Küçükaltan, 2012: 73). Porter ve Smith (1970)'i izleyen Mowday ve arkadaşları (1982: 27)'na göre örgütsel bağl1lığın karakterize edilebilmesi için, en az üç faktör bulunmalıdır: a. Örgütün amaçlarını ve değerlerini kabul etme ve sıkı sıkıya bağlanma, b. Örgütün amaçlarına ulaşabilmesi için gayret gösterme, c. Örgütün bir üyesi olarak kalma konusunda güçlü bir isteğe sahip olma. Bu üç faktör yoksa örgütsel bağll1ık yoktur. Diğer bir tarife göre örgütsel bağl1lık, işgörenlerin istek ve ihtiyaçlarının tatminin bir sonucudur (Usta ve Küçükaltan, 2012: 71). Örgütsel bağl1lık, kişilerin örgüte gösterdikleri pasif bir sadakatten çok, kişilerin örgütün başarılı olması ve hedeflerine ulaşmasına yardımcı olabilmek için bir şeyler yapma isteğini ortaya koydukları daha aktif bir ilişkiyi kapsamaktadır (İnce ve Gül, 2005: 1; Steers, 1981: 327, Akt. Çetin vd., 2011: 63).

Meyer ve Allen 1984'deki çalışmalarında örgütsel bağlılığı önce duygusal (affective) ve devamlılık (continuance) bağlılı̆̆ olarak iki boyutta incelemişler, sonraki çalışmalarında normatif (normative) bağl1lı boyutunu modellerine ekleyerek üç bileşenli örgütsel bağll1ık modeline erişmişlerdir (Allen ve Meyer, 1996: 253). Meyer ve Allen (1990)'1n ortaya koyduğu örgütsel bağl111k yaklaşımında, tutumsal ve davranışsal yaklaşımlar ve onların tamamlayıcı ilişkileri birlikte ele alınmış; işgörenin örgütle ilgili hisleri ve/veya inançları psikolojik bir durum olarak değerlendirilmiştir (Özutku, 2008: 82).

Wiener (1982: 421)'e göre örgütsel bağl1lık seviyeleri yüksek işgörenleri bu yönde davranmaya iten sebep işgörenlerin davranışlarının sonuçlarını düşünmeleri veya bir menfaat beklentisi içinde olmaları değil yaptıkları davranışların doğru ve ahlaki olduğunu düşünmeleridir. Duygusal bağl1lık örgütle özdeşleşme, örgüte dâhil olma ve duygusal olarak eklenmek anlamına gelir. Bu sayede, çalışanlar örgütte kalmak için güçlü duygusal bağl1lık duyarlar, çünkü böyle isterler. Devam bağlılı̆ğ ise örgütten ayrılma durumunda ortaya çıkacak maliyetle ilgilidir. Güçlü devam bağl1lığı olan çalışanlar örgütte kalırlar, çünkü böyle yapmak zorundadırlar. Son olarak normatif bağl1lık, örgütte kalmaya yönelik algılanan zorunluluğu ifade etmektedir (Allen ve Meyer, 1996: 253). Bir başka deyişle, bireylerin kendilerine kurumun misyon ve değerleri ile ilgili görev biçmesinden dolayı, örgütte kalmak zorunda oldukları için örgütte kalmalarıdır (Gürbüz ve Bekmezci, 2012: 193). Güçlü normatif bağl1lı̆a sahip çalışanlar örgütte kalırlar, çünkü böyle yapmaları gerekir. Görüldüğü gibi, bağl1lığın her üç bileşeni de bir örgütte kalmak ya da örgütten ayrılmak gibi basit etkilere sahiptir, ama bunun ötesinde kavramsal olarak birbirlerinden oldukça farklıdır (Allen ve Meyer, 1996: 253).

\section{3. ÖRGÜTSEL SESSIZLIKK KAVRAMI}

Sessizlik iklimi, problemler ya da konular karşısında konuşmanın faydasız ve/veya tehlikeli olduğuna dair örgütte çalışanlar arasında yaygın olarak paylaşılan algıları ifade eder. Bu iklim hakimse konuşmaya nazaran sessizlik daha baskındır (Morrison ve Milliken, 2000: 708). Çalışanların örgüt sorunlarıyla ilgili görüş ve endişelerini dile getirmede isteksiz davrandıkları görülmektedir. Ancak bu 
durum insan kaynağını merkezine alan yeni yönetim paradigmaları ile çelişmektedir (Çakıcı, 2007: 145). Örgütsel sessizlik, içeriği sayesinde, sosyal etki ve uyma davranışı çerçevesinden de duygu bulaşması/sosyal bulaşma çerçevesinden de tarif edilebilir. Örgütsel sessizlik kavramı, ilk kez Morrison ve Milliken (2000: 706) tarafından ortaya atılmış ve "örgütsel değişime ve gelişime engel olan bir tehlike ve çoğulcu bir örgüt geliştirmeye mani olan kolektif bir fenomen” olarak tanımlanmıştır. Pinder ve Harlos (2001: 334)'a göre işgören sessizliği, değişimi etkileyebilme ya da düzeltebilme yeteneğindeki insanların, örgütsel durumlara ilişkin konularda, davranışsal, bilişsel, duygusal değerlendirmeleri hakkındaki samimi düşüncelerini esirgemesidir. Sessizlik doğasının muğlak ve karmaşık olmasına bağlı olarak sessiz kalma sebebini ayırt etmek zordur. Anlaşılma ve yorumlanma zorluğu yönetim yazınında da kabul edilmektedir (Çakıc1, 2007: 148). Literatürde örgütsel sessizlik kavramı farklı yazarlarca farklı boyutlarla tanımlanmıştır. Bu çalışma kapsamında Van Dyne, Ang ve Botero (2003) tarafından yapılan örgütsel sessizlik sınıflandırması tercih edilmiştir. Van Dyne ve arkadaşları örgütsel sessizliğin çok boyutlu yapıda olduğunu vurgulamakta; bunları kabullenici (Acquiescent Silence), savunmac1 (Defensive Silence) ve ilişkisel sessizlik (ProSocial Silence) olarak modellemişlerdir. Kabullenici sessizlik, çalışanların herhangi bir konu, sorun ya da durum ile ilgili gelişmelere rıza göstermesinin sonucunda, söz konusu durum hakkındaki görüş, düşünce ve bilgilerini söylememesi; savunmacı sessizlik, çalışanların kendilerini korumak amacıyla sahip oldukları düşünce, bilgileri ya da fikirleri korkuya dayalı olarak kendilerine saklamaları; ilişkisel sessizlik -literatürdeki Örgütsel Vatandaşlık Davranışı kavramını ve bu kavramın içerisinde barındırdığı çalışanların davranışlarının ilişkisel formları incelenerek- çalışanların iş ile ilgili fikirlerini, bilgilerini veya görüşlerini, özgecilik ya da birliktelik güdülerine dayanarak diğer insanların ya da örgütün yararını sağlamak amacıyla kendilerine saklamaları olarak açıklanmıştır (Van Dyne vd., 2003: 1366, 1367, 1368). Sessizliğin özel tiplerine örnekler Tablo 1'dedir. 
Tablo1. Sessizliğin Özel Tiplerine Örnekler

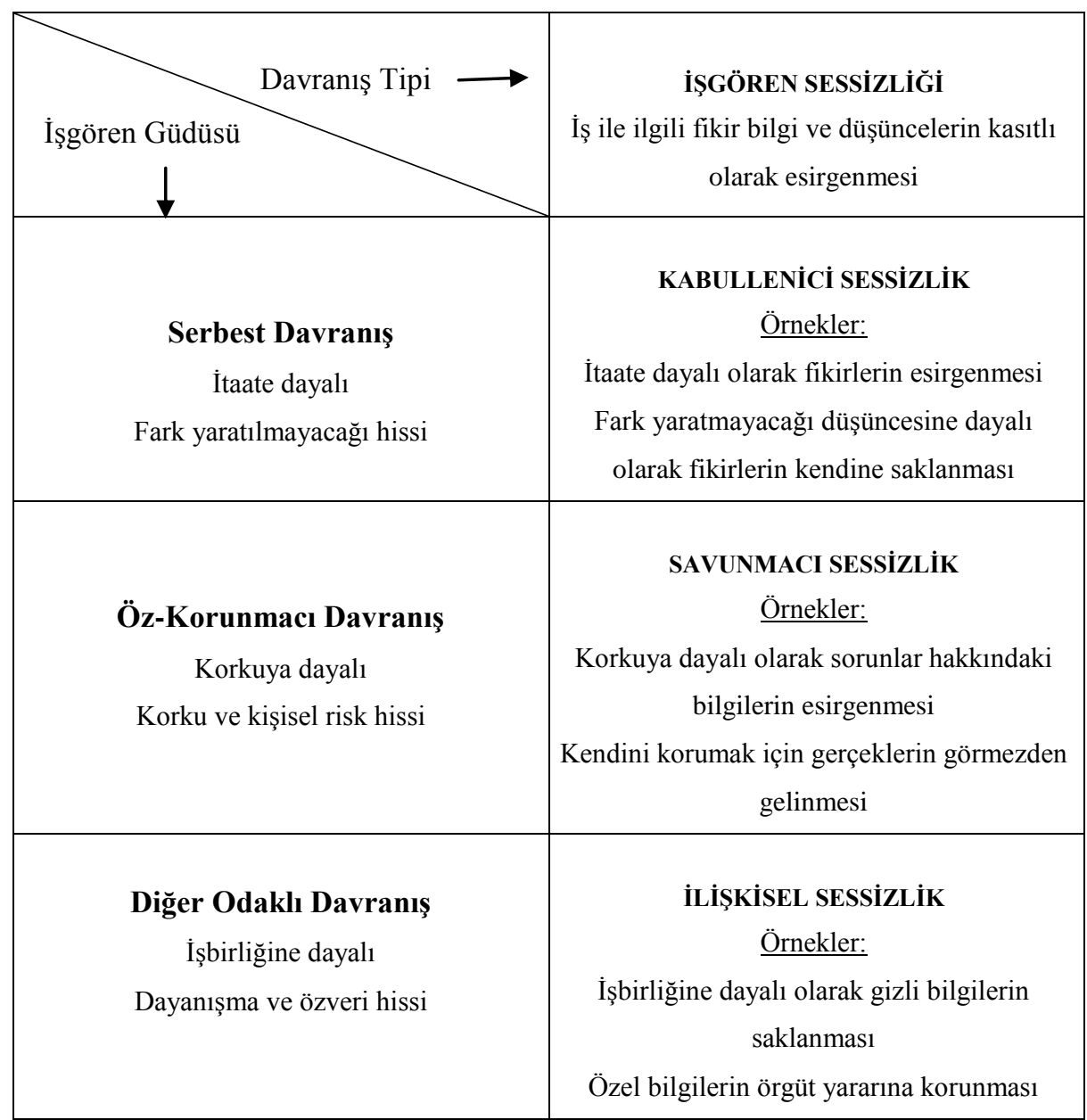

Kaynak: Van Dyne, Ang ve Botero, 2003, s.1363

Çoğu örgüt teorisyeni ve araştırmacı, sessizliğin "sesin olmaması" tanımını benimsemekte, sessizliğin iletişimsel önemi ile davranışsal, duygusal ve bilişsel bileşenlerini göz ardı etmektedir (Pinder ve Harlos, 2001: 337). Sessizlik asla zıddını ima etmekten vazgeçmez ve onun varlığına bağlıdır. Tıpkı "aşağı" olmadan "yukarı" veya "sağ" olmadan "sol" un olamayacağı gibi; insan, sessizliğini tanımlamak için sesin ya da dilin çevresini kabul etmelidir (Sontag, 1969: 5).

Sessizlik iklimi iki ortak inanışla karakterize edilebilir: a. Problemler hakkında konuşmaya değmez. b. Fikirlerini ya da endişelerini söylemek tehlikelidir (Morrison ve Milliken, 2000: 714). Sessizliğin nedenlerinin sesin nedenlerine nazaran yanlış anlaşılma ve yanlış yorumlanma olasıllığı daha yüksektir (Dyne vd., 2003: 1389). Çünkü durum daha muğlâktır. Sessizliğin de bir iletişim türü olduğunun akıldan çıkarılmaması gerekir. Sessizliğe neden olan kavramlara bakıldığında Çakıcı (2007)'nın ‘Örgütlerde Sessizlik: Sessizliğin Teorik Temelleri ve Dinamikleri’ çalışmasında örgütlerde sessizliğin kültür ile ilişkisi teorik olarak incelendiği görülmektedir. Çalışmada toplumsal kültürel normların sessizlik üzerindeki etkisi kabul edilmekle birlikte, yönetsel inançları besleyen "güç mesafesi” kültürüne de değinilmiştir. Kılıç ve arkadaşları (2014) ise birbirinden farklı sektörlerde 
çalı̧̧anlar üzerindeki yaptıkları çalışmada örgütsel kültür çerçevesinde dönüştürücü liderlik tarzının sergilendiği örgütlerde çalışanların sessiz kalmadıklarını, etkileşimci ve tam serbesti tanıyan liderlik tarzının sergilendiği örgütlerde ise sessiz kalmayı tercih ettiklerini ortaya koymuştur.

\section{4. ÖRGÜTSEL BAĞLILIK - ÖRGÜTSEL SESSİZLİK İLISSTKİSI}

Çalışmanın bu kısmında, örgütsel bağlılık ve örgütsel sessizlik ilişkisini konu edinen çalışmalar ve sonuçlarına değinilecektir. Deniz ve arkadaşları (2013: 691) İstanbul'da özel bir hastane çalışanları üzerine yaptıkları çalışmada duygusal bağlılık ve savunmacı sessizlik arasında anlamlı ve negatif bir ilişki olduğunu tespit etmişlerdir. Eroğlu ve arkadaşları (2011: 120) duygusal bağl1lık ile kabullenici sessizlik ve korunma sessizliğinin birbirlerinden bağımsız olmadıkları bulgusuna erişmiş, devam bağlılığı ile kabullenici sessizlik ve koruma sessizliğinin birbirlerinden bağımsız olmadıklarını ortaya koymuştur. Normatif bağl1lık ile kabullenici sessizlik, korunma sessizliği ve koruma sessizliğinin birbirlerinden bağımsız olmadıkları gözlemlenmiştir. Ayrıca, devam bağlılı̆̆ı alt boyutu ile koruma sessizliği alt boyutu ve normatif bağl1lık alt boyutu ile koruma sessizliği alt boyutu arasında da pozitif yönlü anlamlı ilişkiler bulunmuştur. Köse (2014: 34)'nin dezavantajlı okullarda çalışan öğretmenler üzerinde yaptığı çalışmada örgütsel bağl1lık düzeyleri ile örgütsel sessizlik arasındaki ilişkilerin negatif yönde ve anlamlı olduğu saptanmıştır. Buna göre öğretmenlerin örgütsel sessizlik düzeyindeki artışa paralel olarak örgütsel bağl1lık düzeylerinin düştüğü tespit edilmiştir. Nikmaram ve arkadaşları (2012: 1271)'nın Tahran Üniversitesi'nde, memur ve profesörler üzerine yaptıkları araştırmada, sessizlik iklimi algısı ve çalışanların sessizlik davranışı ile örgütsel bağl1lık arasında negatif ilişki bulunmuştur. Panahi ve arkadaşları (2012: 743) Payame Noor Üniversitesi'nde çalışanlarla yürüttükleri çalışmada, örgütsel bağlılık ve sessizlik davranışı arasında istatistikî olarak anlamlı ve negatif ilişki tespit etmişlerdir. Ülker ve Kanten (2009: 123-124) makine ve gıda sektörlerinde yaptıkları çalışmada işgören sessizliği ile duygusal bağlılık arasında pozitif yönde anlamlı ilişki bulmuşlar, işgörenlerin duygusal bağlılıklarındaki değişkenliğin \%51'inin, sessizlik iklimi ve işgören sessizliği tarafından açıklandığını ortaya koymuşlardır. Vakola ve Bouradas (2005: 452)'1n, teknoloji firması çalışanlarıyla yürüttükleri araştırmada sessizlik davranışı ve örgütsel bağlılık arasında negatif ilişki bulunmuş, sessizlik arttıkça bağl1lığın azaldığı görülmüştür. Çalışmanın sonuçları örgütsel bağl1lığın en güçlü belirleyicisinin iletişim olanakları olduğunu ortaya koymuştur. Tüm bu çalışmalar bağl1lık ve sessizlik arasındaki ilişkiyi, etkileşimi doğrulamaktadır. Bunlar ışığında metodoloji aşağıdaki gibi kurgulanmıştır.

\section{METODOLOJI}

\subsection{Araştırmanın Amacı}

Araştırmanın amacı, örgütsel sessizlik ve örgütsel bağl1lık kavramlarının birbiriyle ilişkilerini belirlemek ve örgütsel bağl1lık boyutlarının, örgütsel sessizlik boyutları üzerindeki etkisini ortaya koymaktır. Bu bağlamda örgütsel bağlılık boyutlarının bağımsız, örgütsel sesssizlik boyutlarının bağımlı değişken olduğu araştırma modeli Şekil 1'de sunulmuştur. 
Şekil 1. Araştırma Modeli

ÖRGÜTSEL BAĞLILIK ÖRGÜTSEL SESSIZLIKK

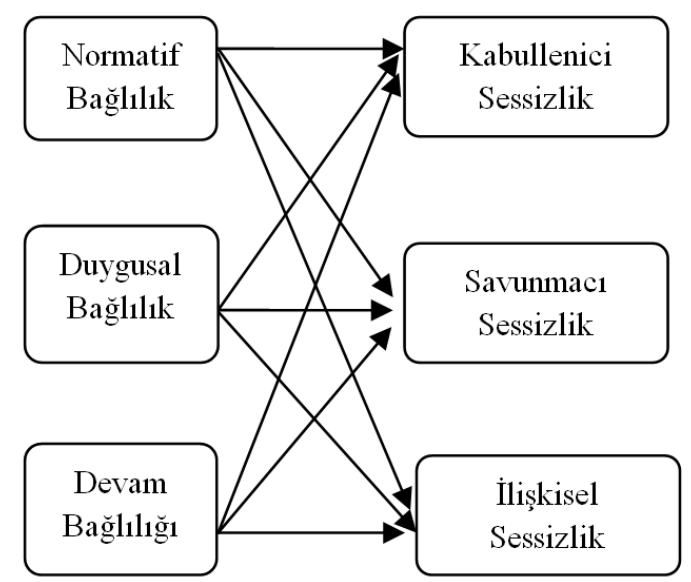

Araştırma modeline yönelik ileri sürülen hipotezler şunlardır:

H1: Örgütsel bağl1lık (normatif, duygusal ve devam) boyutlarının, kabullenici sessizlik üzerinde pozitif etkisi vardır.

H2: Örgütsel bağl1lık (normatif, duygusal ve devam) boyutlarının, savunmacı sessizlik üzerinde negatif etkisi vardır.

H3: Örgütsel bağl1lık (normatif, duygusal ve devam) boyutlarının, ilişkisel sessizlik üzerinde pozitif etkisi vardır

\subsection{Araştırmanın Kapsamı}

Araştırma, İzmir'de Türk Silahlı Kuvvetlerine bağlı Güzelyalı Hava Lisan Okulu çalışanları kapsamında gerçekleştirilmiştir. Örneklem grubunun evreni temsil etmesi için gerekli sınır sayılarıyla ilgili çalışmalar literatürde yapılmıştır (\%95 güven seviyesinde farklı evren büyüklükleri için örneklem sayıları için bkz. Kurtuluş 1989, Yazıcıŏlu ve Erdoğan 2004: 50). Evrenin belirli olduğu durumlarda ne kadar örnekleme ulaşılması gerektiği, hoşgörü miktarı ve hata olasılıklarıyla kitle genişliklerine göre hesaplanarak elde edilen tablolara göre hata toleransı $\% 5$, güvenilirlik düzeyi $\% 95$ ve kitle genişliği 1000 olduğunda 278 kişilik bir örneklem seçilmesi gerekmektedir. (Yazıcıŏglu ve Erdoğan, 2004: 50). $\mathrm{Bu}$ bağlamda araştırmanın örneklemini, evren içerisinden basit tesadüfî örnekleme yöntemi ile belirlenen 300 çalışan oluşturmaktadır. Çalışanlara uygulanan 300 anketin, 277 tanesi veri analizine uygun bulunmuştur. Dolayısıyla anketlerin geri dönüş oranı \%92'dir. 


\subsection{Araştırmanın Yöntemi}

Araştırmanın yöntemi survey'dir. Anket tekniği kullanılan araştırma, iki aşamada gerçekleşmiştir. Birinci aşamada literatür taraması yapılarak kavramsal çerçeve çizilmiştir. İkinci aşamada kavramsal çerçeveden hareketle hipotezler belirlenip, alan araştırması ile veriler toplanarak uygulama bölümü ortaya konmuştur. $\mathrm{Bu}$ çalışmada veri toplama aracı olarak anket formu kullanılmıştır. Formda demografik ifadeler hariç, tüm ölçeklerde bütün ifadeler beşli Likert tipi şeklinde "tamamen katıllyorum $=5$ " seçeneği ile "kesinlikle katılmıyorum=1" aralığında tasarlanmıştır. Ölçekler basılı olarak katılımcılara ulaştırılmış, doldurulması sağlanmıştır. Araştırma hakkında katılımcılara bilgi verilmiş, verilerin gizliliğinin sağlanacağı bildirilmiş ve gönüllülük esasına göre katılım sağlanmıştır.

Anket formu; demografik sorular, örgütsel sessizlik, örgütsel bağl1lık ölçeklerini kapsayan 3 bölümden ve sırasıyla 4, 15, 18, toplamda 37 soru/ifadeden oluşmaktadır. Örgütsel sessizlik tutumları ikinci bölümde; Dyne vd. (2003) tarafından geliştirilen toplam 15 ifadeden oluşan "Örgütsel Sessizlik Ölçeği” ile ölçülmüştür. Ölçeğin alt boyutlarını 'kabullenici sessizlik (acquiscent silence)', 'savunmacı sessizlik (defensive silence)' ve “ilişkisel sessizlik” (pro-social silence) oluşturmaktadır. Taşkıran (2010) tarafından Türkçeye uyarlanmıştır. "Lehime bir değişiklik yaratacağına inanmadığım için, kendimi geliştirmeye yönelik fikirlerimi ifade etmekten çekinirim", kabullenici sessizlik; "Yöneticimin tepkisinden korktuğum veya çekindiğim için değişime ilişkin fikirlerimi ileri sürmem ve konuşmam.”, savunmacı sessizlik ve "Bu işletme ile olan işbirliğime dayanarak, gizli kalması gereken bilgileri kendime saklarım.” ise ilişkisel sessizlik boyutuna ait ifadelerdendir. Üçüncü bölümde çalışanların örgüte bağl1lığını ölçmeye yönelik 18 ifadeyi içeren Meyer ve Allen'in, 'duygusal bağl1lık (affective commitment)', 'normatif bağlılık (normative commitment)' ve 'devam bağl1lı̆̆ (continuance commitment)' olarak boyutlandırdığı örgütsel bağlılık ölçeği kullanılmıştır. Ölçekte yer alan her boyut 6 ifadeden oluşmaktadır. "Çalışma yaşamımın geri kalan kısmını bu işletmede geçirmek beni çok mutlu eder.", duygusal bağl11ık; "Şu anda işletmeden ayrılmaya karar vermek hayatımda çok fazla şeyi etkiler.", normatif bağl1lık ve son olarak da "Bu işletmede kalmak için kendimi manevi yükümlülük altında hissediyorum.” ise devam bağlılı̆g 1 boyutuna ait ifadelerdendir. Araştırmada elde edilen veriler 15.0 SPSS paket programında analize tabi tutulmuştur.

\subsection{Araştırmanın Kısıtları}

"Sessizlik" ve "bağlllık" gibi konular hem bireysel hem de kurumsal olarak oldukça hassas ve mahremdir. Bu yüzden araştırmanın veri toplamaya ilişkin 'samimi olmama riski' içermesi önemli bir kısıttır. Buna ek olarak araştırma İzmir'de faaliyet gösteren Türk Silahlı Kuvvetleri (TSK) çalışanlarının katılımı ile gerçekleştirilmiş olup, TSK'nın stratejik konumundan dolayı veri toplamaya ilişkin bir takım güçlükler içermesi bir diğer kısıttır. Bunlar ışığında sonuçların genellenmesi mümkün değildir. 


\subsection{Araştırma Bulgularının Sunumu ve Değerlendirilmesi}

Araştırmanın bu bölümünde, İzmir ilinde faaliyet gösteren Güzelyalı Hava Lisan Okulu çalışanlarından anket aracılığı ile elde edilen verilere dayalı yapılan analizlere ilişkin bulgulara yer verilmiştir.

\subsubsection{Demografik Bulgular}

$\mathrm{Bu}$ bölümde çalışanların cinsiyet, yaş, medeni durum ve eğitim düzeylerine ilişkin sorulara yer verilmiştir. Ankete verilen cevaplar, betimleyici istatistikler (frekans, yüzde, ikili karşılaştırma, vb.) kullanılarak analiz edilmiş, aşağıda her biri tablo halinde özetlenmiştir. İlk olarak anket katılımcılarından elde edilen demografik bulgular Tablo 2'de verilmiştir.

Tablo 2. Demografik Bulgular

\begin{tabular}{|c|c|c|}
\hline Değişkenler & N & Yüzde (\%) \\
\hline \hline \multicolumn{3}{|c|}{ Cinsiyet } \\
\hline Kadın & 80 & 28,9 \\
\hline Erkek & 197 & 71,1 \\
\hline \multicolumn{3}{|c|}{ Medeni Durum } \\
\hline Bekâr & 152 & 54,9 \\
\hline Evli & 125 & 45,1 \\
\hline \multicolumn{3}{|c|}{ Yaş } \\
\hline 25 ve altı & 78 & 28,2 \\
\hline $26-35$ & 101 & 36,5 \\
\hline $36-45$ & 71 & 25,6 \\
\hline 46 ve üstü & 27 & 9,7 \\
\hline \multicolumn{3}{|c|}{ Ĕgitim } \\
\hline Temel & 3 & 1,1 \\
\hline Orta & 145 & 52,3 \\
\hline Lisans & 123 & 44,4 \\
\hline Lisansüstü & 6 & $\mathbf{1 0 0 . 0}$ \\
\hline TOPLAM & $\mathbf{2 7 7}$ & \\
\hline &
\end{tabular}

Tablo 2'e bakıldığında ankete katılan çalışanların \%71,1'i erkek, yalnızca \%28,9'u kadındır. Katılımcıların yaklaşık \%55'i bekar, \%45'i bekardır. Yaş aralıklarına bakıldığında katılımcıların \%28,2'si 25 yaş ve altında; \%36,5'i 26-35 yaş aralığında ve \%25,6'sı 36-45 yaş aralığındadır. Çalışanların eğitim durumlarına bakıldığında \%52,3'ünün orta ve \%44,4'ünün lisans düzeyinde olduğu görülmektedir.

\subsubsection{Güvenilirlik ve Geçerlilik}

Bir ölçeğin güvenilir olması tesadüfî hataların ölçme sürecinde ortadan kaldırılması demektir. Ölçeğin güvenirliliğinin ölçülmesinde farklı yöntemler kullanılabilir. Araştırmada tüm ölçekler için güvenirlik testi olarak Cronbach alfa katsayısı kullanılmıştır. Örgütsel sessizlik ölçeğinin güvenilirlik 
katsayısı ilk yapılan analiz neticesinde 0,720 bulunmuştur. Bu değer, ölçeğin oldukça güvenilir olduğu sonucunu vermektedir. Ancak ölçeği oluşturan değişkenlerin, ölçeğin bütünüyle olan korelasyonlarına ve genel katkılarına bakıldığında, p5 değişkeninin ölçeğin genel alpha değerini geçtiği görülmüştür. Dolayısıyla bu değişken çıkartılarak analiz tekrar edilmiş ve Cronbach alfa katsayısı 0,735 bulunmuştur. $\mathrm{Bu}$ değer ile ölçeğin içsel tutarlığa sahip olduğu sonucuna varılmıştır. Örgütsel bağl1lık ölçeğinin katsayısı 0,758 olarak bulunmuştur. Dolayısıyla ankette kullanılan tüm ölçekler oldukça güvenilirdir. Ölçeğin geçerliliği ise, sistematik ve tesadüfî hatalardan arındırıldığg anlamına gelmektedir (Yükselen, 2013: 115). Ölçeklerin geçerliliği faktör analizi ile ölçülmüştür.

\subsubsection{Faktör Analizi}

Faktör analizi değişkenler arasındaki ilişkiyi korelasyon katsayıları aracıllı̆ıyla inceler, daha az sayıda faktöre dönüştürülmesine yardımcı olur (Yükselen, 2013: 199). Çalışmada ölçekteki sorularda yer alan ve her biri bir değişkeni temsil eden sorular faktör analizi ile daha anlaş1lır hale getirilmiştir. Ayrıca ölçeklerin, ayırma (discriminant) ve birleşme (convergent) geçerlilikleri sınanmış ve her bir boyuta ait güvenilirlilik değerleri bulunmuştur.

Araştırmada ilk olarak sessizlik ölçeğine faktör analizi uygulanmıştır. Temel bileşenler ve Varimax faktör rotasyon yöntemleri kullanılarak yapılan birinci faktör analizi sırasında Bartlett'in Küresellik değeri anlamlı ve KMO değeri, tavsiye edilen değerin $(0,60 \geq)$ üzerinde 0.708 olarak bulunmuştur. Analizde her bir faktörde, faktör yükü 0,50 'den daha düşük olan maddeler ve birden fazla faktörde nitelik yükü 0,50 ve üstü olan sonuçlar elimine edilmelidir. İlgili literatürde Hair vd. (1998), Hattie (1985) önerildiği gibi, faktör yüklemesi 0,50nin üzerinde olan değişkenler bir araya getirilerek faktör bileşenleri oluşturulmuştur (Hattie, 1985; Hair vd., 1998'den alıntılayan İşler ve Özdemir, 2010: 127). Dolayısıyla bu noktada faktör yükü 0,50'nin altında gerçekleşen k5 değişkeni ve birden fazla faktör yapısında 0,50 'nin üzerinde faktör yüküne sahip olan p5 değişkeni ölçekten çıkartılmıştır. Faktör analizi bu iki değişken çıkartıldıktan sonra tekrar edilmiştir ve Temel bileşenler ve Varimax faktör rotasyon yöntemleri kullanılarak yapılan ikinci analize göre Küresellik testi (Bartlett's test of sphericity) anlamlı ve KMO değeri, tavsiye edilen değerin üzerinde (0.778) olarak bulunmuştur. Yani elimizdeki verilere faktör analizi yapılmasının uygun olduğu görülmüştür. 
Tablo 3. Örgütsel Sessizlik Boyutları Faktör Yükleri

\begin{tabular}{|c|c|c|c|}
\hline \multicolumn{4}{|c|}{ KMO $=0,778$, Bartlett, $s d=78, p \leq 0,001$} \\
\hline Faktör & $\begin{array}{l}\text { Faktör } \\
\text { Yükü }\end{array}$ & $\begin{array}{c}\text { Açıklanan } \\
\text { Varyans }\end{array}$ & $\begin{array}{c}\text { Alpha } \\
\text { Katsayısı }\end{array}$ \\
\hline 1. Savunmacı Sessizlik & & 28,678 & $\mathbf{0 , 7 4}$ \\
\hline $\begin{array}{l}\text { Yöneticimin tepkisinden korktuğum veya çekindiğim için } \\
\text { değişime ilişkin fikirlerimi ileri sürmem ve konuşmam. }\end{array}$ & ,766 & & \\
\hline $\begin{array}{l}\text { Bu işletmede çalışmaya devam edebilmek için iş ile ilgili } \\
\text { olumsuz durumları görmezden gelirim. }\end{array}$ & 670 & & \\
\hline $\begin{array}{l}\text { İşletmedeki devamlılığımı korumak amacıyla eksik hususlar } \\
\text { düzeltmeye yönelik var olan görüşlerimi açıklamaktan } \\
\text { sakınırım. }\end{array}$ & 639 & & \\
\hline $\begin{array}{l}\text { Yöneticimin tepkisinden korktuğum veya çekindiğim için iş } \\
\text { ile ilgili bilgilerimi kendime saklarım. }\end{array}$ & ,745 & & \\
\hline $\begin{array}{l}\text { Yöneticimin tepkisinden korktuğum veya çekindiğim için } \\
\text { ortaya çıkan problemlere yönelik çözümlerimi } \\
\text { geliştirmekten çekinirim. }\end{array}$ &, 594 & & \\
\hline 2. İlişkisel Sessizlik & & 16,090 & 0,798 \\
\hline $\begin{array}{l}\mathrm{Bu} \text { işletme ile olan işbirliğime dayanarak, gizli kalmas } \\
\text { gereken bilgileri kendime saklarım. }\end{array}$ & ,733 & & \\
\hline $\begin{array}{l}\mathrm{Bu} \text { işletme ile ilgili sırları açılamam konusunda } \\
\text { başkalarından gelen baskılara direnirim. }\end{array}$ &, 582 & & \\
\hline $\begin{array}{l}\text { Bu işletmeye zarar verebilecek bilgileri açılamay } \\
\text { reddederim. }\end{array}$ &, 581 & & \\
\hline $\begin{array}{l}\text { Bu işletmeye yararlı olmak amacıyla özel bilgilerimi } \\
\text { saklarım. }\end{array}$ & ,692 & & \\
\hline 3. Kabullenici Sessizlik & & 22,142 & 0,723 \\
\hline $\begin{array}{l}\begin{array}{l}\text { Alınacak kararlara rıza gösteren biri olduğumdan } \\
\text { düşüncelerimi kendime saklarım. }\end{array} \\
\end{array}$ & ,780 & & \\
\hline $\begin{array}{l}\text { Problemlere çözüm üretme noktasında görüşlerimi kendime } \\
\text { saklarım. }\end{array}$ & ,762 & & \\
\hline $\begin{array}{l}\text { Lehime bir değişiklik yaratacağına inanmadı̆̆ım için, } \\
\text { kendimi geliştirmeye yönelik fikirlerimi ifade etmekten } \\
\text { çekinirim. }\end{array}$ & ,736 & & \\
\hline $\begin{array}{l}\text { Benimle ilgili olmadığı için değişime yönelik yapılan } \\
\text { öneriler hakkında konuşmakta isteksizimdir. }\end{array}$ & 652 & & \\
\hline Toplam Açıklanan Varyans & & 66,910 & \\
\hline
\end{tabular}

İlgili faktör yükleri Tablo 3'de görülmektedir. Temel bileşenler faktör analizinde özdeğer (eigenvalue) istatistiği 1 ve üstü olan bileşenler dikkate alınmış ve literatürdeki çalışmalarla paralel olarak üç faktörlü bir yapı ortaya çıkmıştır. Ayrıca bu değişkenlerin yüklendikleri faktörlerin tamamı tarafından açıklanan toplam varyans \% 66,910'dur. Tablo 3'de görüldüğü üzere toplam 5 soruyu içeren ilk faktör yapısı, içerdiği değişken ifadeleri nedeniyle "savunmacı sessizlik boyutu"; 4 sorunun oluşturduğu ikinci faktör ise "ilişkisel sessizlik boyutu"; 4 sorunun oluşturduğu üçüncü faktör ise 
"kabullenici sessizlik boyutu" olarak adlandırılmaktadır. Araştırmada, faktör analizi sonucu meydana gelen faktör yüklerinin 0.50 değerinin üzerinde olması ve ölçekte ortaya konulan faktör yapısının, ortalama varyansın 0.50 'sinden daha fazlasını açıklaması, ayrıca değişkenlerin, ait oldukları faktörler dışındaki diğer faktörlerle yüksek korelâsyon değerlerine sahip olmamaları araştırmada kullanılan ölçeğin, ayırma (discriminant) ve birleşme (convergent) geçerliliklerini sağladığını da göstermektedir (Igbaria vd., 1994). Ayrıca her bir boyuta ait güvenilirlik analizleri de hesaplanmıştır. Yapılan güvenirlilik testi sonucunda Cronbach Alfa değerleri savunmacı sessizlik boyutunun $\alpha=0,74$; ilişkisel sessizlik boyutunun $\alpha=0,798$ ve son olarak kabullenici sessizlik boyutunun $\alpha=0,723$ olarak bulunmuştur.

Tablo 4. Örgütsel Bağlılık Boyutları Faktör Yükleri

\begin{tabular}{|c|c|c|c|}
\hline \multicolumn{4}{|c|}{ KMO=0,820, Bartlett, $s d=78, p \leq 0,001$} \\
\hline Faktör & \begin{tabular}{|l|} 
Faktör \\
Yükü \\
\end{tabular} & \begin{tabular}{|l|} 
Açıklanan \\
Varyans \\
\end{tabular} & $\begin{array}{l}\text { Alpha } \\
\text { Katsayısı }\end{array}$ \\
\hline 1. Normatif Bağlılık & & 20,323 & 0,758 \\
\hline $\begin{array}{l}\text { Bu işletmede kalmak için kendimi manevi yükümlülük } \\
\text { altında hissediyorum. }\end{array}$ &, 764 & & \\
\hline $\begin{array}{l}\text { Benim için avantajlı da olsa, işletmeden şu anda } \\
\text { ayrılmanın doğru olmadığını hissediyorum. }\end{array}$ & ,690 & & \\
\hline İşletmeden şimdi ayrılsam kendimi suçlu hissederim. & ,613 & & \\
\hline $\begin{array}{l}\text { Buradaki insanlara karşı yükümlülük hissettiğim için } \\
\text { işletmeden şu anda ayrılmazdım. }\end{array}$ &, 566 & & \\
\hline Çalıştığım bu işletmeye çok şey borçluyum. &, 541 & & \\
\hline $\mathrm{Bu}$ işletme benim sadakatimi hak ediyor. &, 534 & & \\
\hline $\begin{array}{l}\text { Eğer bu işletmeye kendimden çok fazla fedakârlık etmiş } \\
\text { olmasaydım, başka yerde çalışmayı düşünebilirdim. }\end{array}$ &, 519 & & \\
\hline 2. Duygusal Bağlılık & & 17,786 & 0,786 \\
\hline $\begin{array}{l}\text { Çalışma yaşamımın geri kalan kısmını bu işletmede } \\
\text { geçirmek beni çok mutlu eder. }\end{array}$ &, 846 & & \\
\hline $\begin{array}{l}\text { Bu işletmenin problemlerini gerçekten benim } \\
\text { problemimmiş gibi hissederim. }\end{array}$ &, 814 & & \\
\hline $\begin{array}{l}\text { Bu işletmeye kendimi duygusal olarak bağlı } \\
\text { hissediyorum. }\end{array}$ &, 761 & & \\
\hline 3. Devam Bağlılığı & & 17,615 & 0,735 \\
\hline \multicolumn{4}{|l|}{$\begin{array}{l}\text { Şu anda işletmeden ayrılmaya karar vermek hayatımda } \\
\text { çok fazla şeyi etkiler. }\end{array}$} \\
\hline \multicolumn{4}{|l|}{$\begin{array}{l}\text { Bu işletmeden ayrılmak istesem de kısa sürede iyi bir iş } \\
\text { bulabilmem benim için çok zor. }\end{array}$} \\
\hline \multicolumn{4}{|l|}{$\begin{array}{l}\text { İşletmeden ayrılmayı düşünmek için çok az seçeneğim } \\
\text { olduğunu hissediyorum. }\end{array}$} \\
\hline Toplam Açıklanan Varyans & \multicolumn{3}{|c|}{55,723} \\
\hline
\end{tabular}

İkinci olarak bağl1lık ölçeğine ilişkin faktör analizi yapılmıştır. Temel bileşenler ve Varimax faktör rotasyon yöntemleri kullanılarak yapılan birinci faktör analizi sırasında Bartlett'in Küresellik değeri anlamlı ve KMO değeri, tavsiye edilen değerin $(0,60 \geq)$ üzerinde 0.79 olarak bulunmuştur. Ancak yukarıda daha önce belirtildiği gibi yapılan faktör analizinde her bir faktörün ve her bir niteliğin tek bir 
faktöre yüklenmiş olması ve faktör yüklerinin 0,50’nin üzerinde gerçekleşmesi beklenir. Dolayısıyla bu noktada duygusal bağl1lık değişkenlerinden faktör yükü 0,50'nin altında gerçekleşen d4, d5 ve d6 değişkenleri ve birden fazla faktör yapısında devam bağlılığı değişkenlerinden 0,50'nin üzerinde faktör yüküne sahip olan de4 değişkeni ölçekten çıkartılmıştır. Faktör analizi bu dört değişken çıkartıldıktan sonra tekrar edilmiştir ve Temel bileşenler ve Varimax faktör rotasyon yöntemleri kullanılarak yapılan ikinci analize göre Küresellik testi (Bartlett's test of sphericity) değeri anlamlı ve KMO değeri, tavsiye edilen değerin çok üzerinde (0.820) olarak bulunmuştur. Yani elimizdeki verilere faktör analizi yapılmasının uygun olduğu görülmüştür. Temel bileşenler faktör analizinde özdeğer (eigenvalue) istatistiği 1 ve üstü olan bileşenler dikkate alınmış ve literatürdeki çalışmalarla paralel olarak üç faktörlü bir yapı ortaya çıkmıştır. Ayrıca bu değişkenlerin yüklendikleri faktörlerin tamamı tarafından açıklanan toplam varyans \% 55,723'dür. İlgili faktör yükleri Tablo 4'de görülmektedir. Buna göre toplam 7 soruyu içeren ilk faktör yapısı, içerdiği değişken ifadeleri nedeniyle "normatif bağlılık boyutu"; 3 sorunun oluşturduğu ikinci faktör ise "devam bağl1lı̆̆ boyutu” ve 3 sorunun oluşturduğu üçüncü faktör ise "duygusal bağl1lık boyutu" olarak adlandırılmaktadır. Bu analizde farklı olarak, literatürde devam bağl1lığını açıkladığı düşünülen de5 olarak ifade edilen değişken normatif bağl11ık boyutuna dâhil olmuştur. Araştırmada, faktör analizi sonucu meydana gelen faktör yüklerinin 0.50 değerinin üzerinde olması ve ölçekte ortaya konulan faktör yapısının, ortalama varyansın 0.50 'sinden daha fazlasını açıklaması, ayrıca değiş̧kenlerin, ait oldukları faktörler dışındaki diğer faktörlerle yüksek korelâsyon değerlerine sahip olmamaları araştırmada kullanılan ölçeğin, ayırma (discriminant) ve birleşme (convergent) geçerliliklerini sağladığını da göstermektedir (Igbaria vd., 1995). Ayrıca her bir boyuta ait güvenilirlik analizleri de hesaplanmıştır. Yapılan güvenirlilik testi sonucunda Cronbach Alfa değerleri normatif bağl1lı boyutunun $\alpha=0,74$; duygusal bağl1lık boyutunun $\alpha=0,786$ ve son olarak devam bağl1lı̆̆ boyutunun $\alpha=0,735$ olarak bulunmuştur.

\subsubsection{Korelasyon Analizi}

Değişkenler arasındaki karşılıklı ilişkiyi ve bu ilişkinin yönünü belirlemek için en sık kullanılan istatistik yöntemi korelasyon analizidir. Çalışmanın bu aşamasında faktör analizi neticesinde elde edilen bağlılık boyutları (normatif, devam ve duygusal) ile sessizlik boyutları (kabullenici, savunmacı ve ilişkisel) arasındaki ilişki Spearman korelasyon analizi ile ölçülmüştür.

Tablo 5. Savunmacı Sessizlik Boyutu ile Bağlılık Boyutları İlişkisi

\begin{tabular}{|l|c|l|c|l|}
\hline Boyutlar & Savunmacı & Normatif & Duygusal & Devam \\
\hline Savunmacı & 1 & & & \\
\hline Normatif & $-0,90$ & 1 & & \\
\hline Duygusal & $-0,249^{* *}$ & 0,02 & 1 & \\
\hline Devam & $\mathbf{- 0 , 1 7 9 * *}$ & 0,10 & 0,08 & 1 \\
\hline
\end{tabular}

$* \mathrm{p} \leq 0.05, * * \mathrm{p} \leq 0.01$ 
Yapılan analize göre ilk olarak bağlılık boyutları ile sessizlik ölçeğinin savunmacı boyutu arasındaki ilişki Tablo 5'de görülmektedir. Tabloya bakıldığında sessizlik ölçeğinin savunmacı boyutu ile $(\mathrm{p} \leq 0.01)$ düzeyinde duygusal ve devam boyutları arasında anlamlı, negatif ve zayıf bir ilişki olduğu görülmektedir.

Tablo 6. İlişkisel Sessizlik Boyutu ile Bağlılık Boyutları İlişskisi

\begin{tabular}{|l|c|c|c|l|}
\hline Boyutlar & İlişkisel & Normatif & Duygusal & Devam \\
\hline İlişkisel & 1 & & & \\
\hline Normatif & $0,122^{*}$ & 1 & & \\
\hline Duygusal & $0,153^{* *}$ & 0,00 & 1 & \\
\hline Devam & $0,316^{* *}$ & 0,00 & 0,00 & 1 \\
\hline
\end{tabular}

$* \mathrm{p} \leq 0.05, * * \mathrm{p} \leq 0.01$

Tablo 6'ya bakıldığında sessizlik ölçeğinin ilişkisel boyutu ile normatif boyut arasında ( $\mathrm{r}=0,122$; $\mathrm{p} \leq 0.05$ ) anlamlı pozitif ve zayıf düzeyde bir ilişki görülmektedir. Ayrıca ilişkisel boyut ile duygusal boyut arasında $(\mathrm{r}=0,153 ; \mathrm{p} \leq 0.01)$ anlaml, pozitif ve zayıf bir ilişki ve devam boyutu arasında $(\mathrm{r}=0,316$; $\mathrm{p} \leq 0.01) \quad$ anlaml1, kuvvetli ve pozitif ilişki olduğu görülmektedir.

Tablo7. Kabullenici Sessizlik Boyutu İle Bağlılık Boyutları İlişkisi

\begin{tabular}{|l|c|c|c|c|}
\hline Boyutlar & Kabullenici & Normatif & Duygusal & Devam \\
\hline Kabullenici & 1 & & & \\
\hline Normatif & $0,113^{*}$ & 1 & & \\
\hline Duygusal & $0,179^{* *}$ & 0,01 & 1 & \\
\hline Devam & $0,326^{* *}$ & 0,00 & 0,00 & 1 \\
\hline
\end{tabular}

$* \mathrm{p} \leq 0.05, * * \mathrm{p} \leq 0.01$

Tablo 7'ye bakıldığında sessizlik ölçeğinin kabullenici boyutu ile normatif boyut arasında $(\mathrm{r}=0,113 ; \mathrm{p} \leq 0.05)$ anlamlı zayıf ve pozitif düzeyde bir ilişki görülmektedir. Ayrıca kabullenici boyut ile duygusal boyut arasında $(\mathrm{r}=0,179 ; \mathrm{p} \leq 0.01)$ anlamlı, zayıf ve pozitif bir ilişki ve devam boyutu arasında $(\mathrm{r}=0,326 ; \mathrm{p} \leq 0.01)$ anlaml, kuvvetli ve pozitif bir ilişki olduğu görülmektedir.

\subsection{5. Çoklu Regresyon Analizi}

Araştırmanın bu bölümünde, bağlılık ölçeğinin alt boyutlarındaki (normatif, devam ve duygusal) herhangi bir artış ya da azalışın sessizlik ölçeğinin (kabullenici, savunmacı ve ilişkisel) boyutları üzerindeki etkisi çoklu regresyon analizi ile ölçülmüştür. Çoklu regresyon analizi, bir bağımlı değişken ile birden fazla bağımsız değişken arasındaki nedensellik ilişkisinin tespitinde kullanılır (Nakip, 2013: 345). Çoklu regresyon analizinin temel varsayımları normal dağılıma uyma ve çoklu bağlantı problemi taşımıyor olmaları şartları faktör skorlarının değişken olarak kullanılıyor olması nedeniyle sağlanmış olmaktadır (Kalaycı, 2005: 331). Ayrıca çoklu regresyon analizinde değişken ekleme ve eleme metodu (stepwise selection) kullanılmıştır. Bu şekilde modele en çok katkı yapan değişkenler yardımıyla model açıklanabilmektedir (Öztürk, 2005: 260). 
Tablo 8. Bağlıık Boyutlarının Savunmacı Boyut Üzerindeki Etkisi

\begin{tabular}{|l|c|c|c|c|c|c|c|}
\hline & $\mathbf{B}$ & $\mathbf{t}$ & $\mathbf{S i g}(\mathbf{p})$ & $\mathbf{F}$ & $\mathbf{S i g}$ & $\mathbf{R}^{\mathbf{2}}$ & Adj. $^{\mathbf{2}}$ \\
\hline Model A & $-0,249$ & $-4,265$ & 0,00 & 18,190 & 0,00 & 0,162 & 0,159 \\
\hline Model B & $-0,179$ & $-3,106$ & 0,00 & 14,205 & 0,00 & 0,194 & 0,187 \\
\hline \multicolumn{8}{l}{} \\
A Yordayıcı Değişken: Duygusal \\
B Yordayıcı Değişken: Duygusal, Devam
\end{tabular}

İlk olarak bağlılık ölçeğinin alt boyutlarının savunmacı boyut üzerindeki etkisi Tablo 8'de görülmektedir. Buna göre Model A olarak ifade edilen ilk model de yordayıcı değişken yalnızca duygusal bağl11ık boyutudur. Duygusal bağl1lık boyutunun, savunmacı sessizlik boyutu üzerindeki etkisini incelemek üzere kurulan regresyon modelinin istatistiksel olarak anlamlı olduğu ve $(\beta=-0,249)$ $\% 5$ anlamlılık seviyesinde negatif yönde etkilediği görülmektedir. Model genel olarak da anlamlıdır, düzeltilmiş $\mathrm{R}^{2}$ değeri ise 0,159 'dur. Yani duygusal bağl1l1k boyutu, savunmacı sessizlik boyutunun yaklaşık \%16'sını açıklamaktadır. Ayrıca duygusal bağlılıktaki bir birimlik artış, sessizlik boyutunda \%25'lik bir azalışa neden olmaktadır. Tablo 8'de görüldüğü üzere ikinci model ise duygusal ve devam bağl1lığı boyutlarını yordayıcı değişken olarak ele almıştır. Dolayısıyla normatif boyut modellere dâhil edilmemiştir. İkinci modelin de istatistiksel olarak anlamlı olduğu ve $(\beta=-0,179)$ ve $\% 5$ anlamlılık seviyesinde negatif yönde etkilediği görülmektedir. Model genel olarak da anlamlıdır, düzeltilmiş $\mathrm{R}^{2}$ değeri ise $0,187^{\prime}$ dir. Modelin açıklayıcılık gücü birinci modelden biraz daha fazladır. Ayrıca devam bağlılı̆̆ındaki bir birimlik artış, savunmacı sessizlik boyutunda yaklaşık \%18'lik bir azalışa neden olmaktadir.

Tablo 9. Bağlılık Boyutlarının İlişkisel Boyut Üzerindeki Etkisi

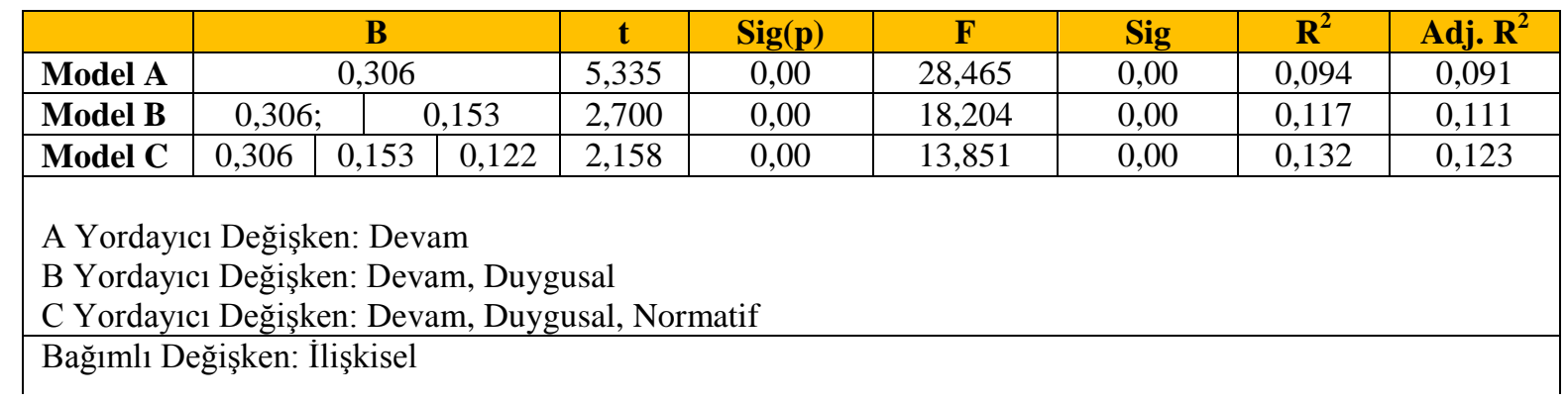

Tablo 9'da bağlılık boyutlarının, ilişkisel sessizlik alt boyutu üzerindeki etkisini ortaya koyan çoklu regresyon analizi sonuçları görülmektedir. Buna göre üç farklı model önerilmiştir ve 3. Model en yüksek açıklayıcı güce sahip olan modeldir. 1. Modelde yordayıcı değişken olarak devam boyutu ele alınmıştır. Devam bağlılığı boyutunun, ilişkisel sessizlik boyutu üzerindeki etkisini incelemek üzere kurulan regresyon modelinin istatistiksel olarak anlamlı olduğu ve $(\beta=0,306)$ ve $\% 5$ anlamlılık 
seviyesinde pozitif yönde etkilediği görülmektedir. Model genel olarak da anlamlıdır, düzeltilmiş $\mathrm{R}^{2}$ değeri ise 0,091'dir. Yani devam bağlılı̆̆ boyutu, ilişkisel sessizlik boyutunun yaklaşık \%9'unu açıklamaktadır. Ayrıca duygusal bağl1lıktaki bir birimlik artış, sessizlik boyutunda \%31'lik bir artışa neden olmaktadır. Tablo 9'da görüldüğü üzere ikinci model ise devam ve duygusal bağl1lık boyutlarını yordayıcı değişken olarak ele almıştır. İkinci modelin de istatistiksel olarak anlamlı olduğu ve duygusal bağl1lık boyutunun $(\beta=0,153)$ ve $\% 5$ anlamlılık seviyesinde pozitif yönde etkilediği görülmektedir. Model genel olarak da anlamlıdır, düzeltilmiş $\mathrm{R}^{2}$ değeri ise 0,11 'dir. Ayrıca duygusal bağlılıktaki bir birimlik artış, ilişkisel sessizlik boyutunda yaklaşık \%15'lik bir artışa neden olmaktadır. Üçüncü model ise en yüksek açıklayıcı güce sahiptir ve düzeltilmiş $\mathrm{R}^{2}$ değeri \%12'dir. Üçüncü model de devam, duygusal ve normatif bağlılık yordayıcı değişken olarak yer almaktadır. Kurulan model istatistiksel olarak anlamlıdır ve normatif bağl1lık boyutunun $(\beta=0,122)$ ve $\% 5$ anlamlılık seviyesinde pozitif yönde etkilediği görülmektedir. Normatif bağlılık boyutundaki bir birimlik artış ilişkisel boyutu \%12 artırmaktadir.

Tablo 10. Bağlılık Boyutlarının Kabullenici Boyut Üzerindeki Etkisi

\begin{tabular}{|c|c|c|c|c|c|c|c|c|c|}
\hline & \multicolumn{3}{|c|}{ B } & $\mathbf{t}$ & $\operatorname{Sig}(p)$ & $\mathbf{F}$ & Sig & $\mathbf{R}^{2}$ & Adj. R $^{2}$ \\
\hline Model A & \multicolumn{3}{|c|}{0,326} & 5,709 & 0,00 & 32,596 & 0,00 & 0,106 & 0,103 \\
\hline Model B & 0,326 ; & & 179 & 3,188 & 0,02 & 21,921 & 0,00 & 0,138 & 0,132 \\
\hline Model C & 0,326 & 0,179 & 0,113 & 2,030 & 0,04 & 16,154 & 0,00 & 0,151 & 0,141 \\
\hline $\begin{array}{l}\text { A Yorday } \\
\text { B Yorday } \\
\text { C Yorday }\end{array}$ & $\begin{array}{l}\text { Değişk } \\
\text { Değişk } \\
\text { Değişk }\end{array}$ & $\begin{array}{l}\text { n: Dev } \\
\text { n: Dev } \\
\text { : Dev }\end{array}$ & $\begin{array}{l}\text { n } \\
\text { n, Duy } \\
\text { n, Duy }\end{array}$ & $\begin{array}{l}\text { sal } \\
\text { sal, Nol }\end{array}$ & & & & & \\
\hline
\end{tabular}

Tablo 10'da bağl1lık boyutlarının, kabullenici sessizlik alt boyutu üzerindeki etkisi çoklu regresyon analizi sonuçları görülmektedir. Buna göre üç farklı model önerilmiş, 3. Model en yüksek açıklayıcı güce sahip olan modeldir. 1. Modelde yordayıcı değişken olarak devam boyutu ele alınmıştır. Devam bağlılığı boyutunun, kabullenici sessizlik boyutu üzerindeki etkisini incelemek üzere kurulan regresyon modelinin istatistiksel olarak anlamlı olduğu ve $(\beta=0,326)$ ve $\% 5$ anlamlllık seviyesinde pozitif yönde etkilediği görülmektedir. Model genel olarak da anlamlıdır, düzeltilmiş $\mathrm{R}^{2}$ değeri ise 0,103'dür. Yani devam bağl1lı̆̆ boyutu, kabullenici sessizlik boyutunun yaklaşık \%10'unu açıklamaktadır. Ayrıca devam bağlılığındaki bir birimlik artış sessizlik boyutunda \%33'lük bir artışa neden olmaktadır. Tablo 10'da görüldügüü üzere ikinci model ise devam ve duygusal bağl1lık boyutlarını yordayıcı değişken olarak ele almıştır. İkinci modelin de istatistiksel olarak anlamlı olduğu ve duygusal bağl1lık boyutunun $(\beta=0,179)$ ve $\% 5$ anlamlılık seviyesinde pozitif yönde etkilediği görülmektedir. Model genel olarak da anlamlıdır, düzeltilmiş $\mathrm{R}^{2}$ değeri ise 0,13 'dür. Ayrıca duygusal bağlılıktaki bir birimlik artış, kabullenici sessizlik boyutunda yaklaşık \%18'lik bir artışa neden olmaktadır. Üçüncü model ise en yüksek açıklayıcı güce sahiptir ve düzeltilmiş $\mathrm{R}^{2}$ değeri \%14'dür. Üçüncü model de devam, duygusal ve normatif bağlılık yordayıcı değişken olarak yer almaktadır. Kurulan model istatistiksel olarak anlamlıdır ve normatif bağlılık boyutunun $(\beta=0,113)$ ve $\% 5$ anlamlılık seviyesinde 
pozitif yönde etkilediği görülmektedir. Normatif bağl1lık boyutundaki bir birimlik artış kabullenici boyutu $\% 11$ artırmaktadır.

\section{SONUÇ}

Örgütsel bağl1lık ve örgütsel sessizlik kavramlarının birbiriyle ilişkilerini ve örgütsel bağlılık boyutlarının, örgütsel sessizlik boyutları üzerindeki etkisini ortaya koymayı amaçlayan çalışmada sessizlik ve bağlılık alt boyutları arasındaki ilişkiler korelasyon analizi ile ölçülmüştür. Evren askeri okul çalışanlarından oluştuğu için bağlılık düzeyinin yüksek olabileceği düşünülebilir. Yapılan analizler neticesinde boyutlar arasında anlamlı, pozitif ve negatif ilişkiler görülmüştür.

Kabullenici sessizlik, çalışanların mevcut durumu değiştirmek için konuşmaya, çaba sarf etmeye istekli olmadıkları durumu ifade etmektedir (Dyne vd., 2003: 1366). Ayrıca kabullenici sessizlik gösteren çalışanların mevcut durumu değiştirecek alternatif yolların da farkında olmadıkları düşünülmektedir (Pinder ve Harlos, 2001: 349). Çalışmada yapılan korelasyon analizinde kabullenici sessizlik boyutunun, örgütsel bağl1lık boyutlarının üçü (duygusal, devam, normatif) ile de pozitif ve anlamlı bir ilişkili olduğunu göstermektedir. Bu bulgu, Ülker ve Kanten (2009)'in sonuçlarıyla örtüşmektedir. Özellikle devam boyutuyla kuvvetli pozitif bir ilişki olduğu belirlenmiştir. Devam bağlılığı özellikle çalışanların mevcut işlerini değiştirmeleri ile katlanmaları gereken maliyeti odağına almaktadır. Dolayısıyla birey bu maliyete katlanmak istemediği için kabullenici bir tavır takınarak alternatif koşullara bile dikkat etmeden sessizliği tercih etmektedir.

Korkuya dayalı olarak çalışan tarafından geliştirilen savunmacı sessizlik ile örgütsel bağl1lık boyutlarının korelasyonlarına bakıldığında ise negatif bir ilişki ortaya çıkmaktadır. Duygusal ve devam bağlılığı ile savunmacı sessizlik arasında anlamlı, negatif bir ilişki bulunmuştur. Bu bulgu, sessizlik arttıkça örgüte bağlılık azalır diyen çalışmaların (Köse, 2014; Deniz vd., 2013; Vakola ve Bouradas, 2005) sonuçlarıyla örtüşmektedir. Burada özellikle duygusal bağlılık boyutu ile savunmacı sessizlik arasındaki ilişki dikkati çekmektedir. Çalışanın işyerine yönelik olarak aidiyet ve özdeşleşme duygusu arttıkça duygusal olarak işyerine bağlanmaktadır. Dolayısıyla böyle bir durumda iş yerinde korkuya dayalı sessizlik durumunun azalması beklenen bir sonuçtur. Korku kültürünün yoğun yaşandığı bir iş yerinde çalışanın duygusal anlamda bağlanması zaten beklenmeyecektir.

İlişkisel sessizlik boyutu ise, bağlılık boyutlarının her üçü ile de pozitif, anlamlı ilişkiye sahiptir. Bu bulgu, Ülker ve Kanten (2009)'in sonuçlarıyla örtüşmektedir. Ancak özellikle devam boyutu ile ilişkisel sessizlik arasındaki ilişki kuvvetlidir. Bu bulgu, Eroğlu vd. (2011)'nin sonuçlarıyla örtüşmektedir. Devam bağl1lığı bir zorunluluk neticesinde örgüte bağlı olmayı ifade etmektedir. Bu noktada çalışanların zorunluluk nedeniyle örgüte bağlılıklarının artması ya da farklı bir ifade ile örgütü terk etme/ayrılma maliyetine katlanamayan çalışanların ilişkilerini sürdürebilmek için sessizliği tercih ettikleri ileri sürülebilir. 
Boyutlar arasında ilişkinin varlığı incelendikten sonra örgütsel bağl1lık boyutlarındaki artış/azalışların sessizlik boyutları üzerindeki etkisini görmek amacıyla çoklu regresyon analizi uygulanmıştır. Çalışmada önerilen en iyi modeli ortaya çıkartmak ve her bir bağl1lık boyutunun etkisini daha net anlamak için ekleme ve eleme yöntemi (stepwise) kullanılmıştır. Elde edilen bulgulara göre duygusal ve devam bağlılığı, savunmacı sessizlik boyutunu negatif olarak etkilemektedir. Duygusal bağımlılıktaki bir birimlik artış \%25; devam bağl1lığındaki bir birimlik artış \%18 oranlarında savunmacı sessizliği azaltmaktadır. Buna göre örgütlerin çalışanları ile kuracakları duygusal bağın yüksekliği onların aidiyet, özdeşleşme yani duygusal olarak örgütle bütünleşmelerine sebebiyet vermesi, korkuya dayalı sessizliği azaltmaktadır. Örneklemimizin askeri okul çalışanları olduğu düşünüldügünde bu sonuçlar düşündürücüdür. Ayrıca duygusal bağlılığın ilişkisel ve kabullenici sessizlik boyutlarını sırasıyla \%15, \%18 oranlarında ve pozitif olarak etkilediği de ortaya çıkmıştır. Duygusal olarak örgütüne bağılı olan çalışan hem ilişkilerine zarar vermemek hem de mevcut durumu bozmamak için sessizliği tercih edebilmektedir.

Devam bağl1lığının da savunmacı sessizliği negatif olarak etkilemesi düşündürücüdür. Devam bağl1lığ1 yüksek olan çalışanların aslında örgütsel bağl1lıklarının düşük olduğu ve alternatif bir çıkış noktası bulduklarında örgütten ayrılabilecekleri ileri sürülür (Koç, 2009). Bu noktada devam bağl1lığının korku nedeniyle çalışanda sessizliği artırmadığı tam tersine azalttığı belirtilmelidir. Devam bağlılı̆̆ındaki bir birimlik artış ilişkisel sessizlik boyutunu \%31, kabullenici sessizlik boyutunu ise \%33 oranında artırmaktadır. Dolayısıyla zorunluluktan devam bağlılı̆ğ, sadece bireyin bir süre durumu umursamaz biçimde veya mevcut durumu 'şimdilik' koruma amacıyla sessizliğine katkı sağlamaktadır.

Elde edilen bulgularda dikkati çeken bir diğer durum ise normatif bağl111̆ğn -hem korelasyon analizi hem de çoklu regresyon analizinde elde edilen bulgulara göre- ilişkisel ve kabullenici sessizlik boyutları ile arasında zayıf ve pozitif ilişkinin tespit edilmesi, savunmacı sessizlik ile arasında anlamlı bir ilişkinin bulunmamasıdır. Normatif bağlılıktaki bir birimlik artış ilişkisel sessizliği \%12; kabullenici sessizliği \%11 oranında artırmaktadır. Çalışanlarda minnet duygusunun söz konusu olduğu, çalışanların örgütte kalmayı bir borç ve görev olarak kabul ettikleri ve diğer bağlılık türlerinden farklı olan normatif bağl1lıkta ilişkileri ve örgütü zor durumda bırakmamak ya da durumun olduğu gibi kabulu sözkonusu olduğu için sessizliğin tercih etmesi doğal bir sonuçtur. Dolayısıyla normatif bağlılığın, korkuya dayalı olan savunmacı sessizlik ile anlamlı bir ilişkisinin olmaması da olağan karşılanabilir.

Sonuç olarak bakıldığında çalışanların örgüt içinde paylaştıklanı duygu ve düşüncelerin bağl1lık duygularını oluşturduğu ve bu durumun da çalışanın örgüte karşı tutumlarını etkilediği görülmektedir. Sessizlik de aslında çok ciddi bir iletişim biçimidir ve çalışanın örgüte yönelik bir davranışı olarak algılanmalıdır. Çalışanların bağlılık boyutları, bu davranış biçimi ile hem ilişkili hem de etkilidir. Örneklemin, katı ve net kuralların geçerli olduğu askeri okul çalışanlarından (sivil ve asker) oluşması, bağl1lık türlerinin ortaya çıkartılması açısından önemlidir. İleride bu araştırma temelinde, farklı örgüt kültürleri değişkenleri de ilave edilerek karşılaştırmalı bir çalışma yapılabilir. 


\section{KAYNAKÇA}

Akyürek, Ç. E., Toygar Ş. A. ve Şener T. (2013) “Örgütsel Kültür ve Alt Kültürün Örgütsel Bağl1llğa Etkisi: Sağlık Çalışanları Üzerine Bir Araştırma”, Ankara Sağlık Hizmetleri Dergisi, 12 (2): 5562.

Allen, N. J. ve Meyer, J. P. (1996) "Affective, Continuance, and Normative Commitment to the Organization: An Examination of Construct Validity", Journal of Vocational Behavior, 49: 252276.

Altin Gulova, A. - Demirsoy O. (2012) “Örgüt Kültürü ve Örgütsel Bağl1lık Arasındaki İlişki: Hizmet Sektörü Çalışanları Üzerinde Ampirik Bir Araştırma", Business and Economics Research Journal 3(3)2012: 49-76, ISSN: 1309-2448.

Chusmir, L.H. (1982), "Job Commitment and the Organizational Woman", Academy of Management Review, 7(4), 595-602.

Çakıc1, A. (2007) “Örgütlerde Sessizlik: Sessizliğin Teorik Temelleri ve Dinamikleri”, Ç.Ü. Sosyal Bilimler Enstitüsü Dergisi, 16(1): 145-162.

Çetin, F., Basım, H. N. ve Aydoğan, O. (2011) “Örgütsel Bağlılı̆̆ın Tükenmişlik İle İlişkisi: Öğretmenler Üzerine Bir Araştırma”, Selçuk Üniversitesi Sosyal Bilimler Enstitüsü Dergisi, 25, 61-70.

Çetin, F., Şeşen H. ve Basım, H. N. (2012) “Örgüt Kültürünün Rol Ötesi Olumlu Davranışlara Olan Etkisi: Örgütsel Bağl1lığın Aracı Değişken Rolü”, Doğuş Üniversitesi Dergisi, 13 (2): 197-211.

Deniz, N., Noyan A. ve Ertosun Ö. G. (2013) "The Relationship between Employee Silence and Organizational Commitment in a Private Healthcare Company", Procedia - Social and Behavioral Sciences , 99: 691-700.

Dyne, L. V., Ang, S. ve Botero I. C. (2003) “Conceptualizing Employee Silence And Employee Voice As Multidimensional Constructs”, Journal of Management Studies, 40(6): 1359-1392.

Eroğlu, A.H., Adıgüzel, O. ve Öztürk, U.C. (2011) "Sessizlik Girdabı ve Bağlılık İkilemi: İşgören Sessizliği İle Örgütsel Bağlılık İlişkisi ve Bir Araştırma”, Süleyman Demirel Üniversitesi İktisadi ve İdari Bilimler Fakültesi Dergisi, 16(2): 97-124.

Gürbüz, S., ve Bekmezci M. (2012) "İnsan Kaynakları Yönetimi Uygulamalarının Bilgi İşçilerinin İşten Ayrılma Niyetine Etkisinde Duygusal Bağl1lı̆ı̆n Aracılık ve Düzenleyicilik Rolü”, İstanbul Üniversitesi İşletme Fakültesi Dergisi, 41(2), 189-213.

Hattie, J. (1985) "Methodology Review: Assessing Unidimensionality of Tests and ltenls", Applied Psychological Measurement, 9(2): 139-164. 
Igbaria, M., Parasuraman, S., Badawy, M. K. (1994) "Work Experience, Job Involvement and Quality of Work Life Among Information System Personel”, MIS Quarterly ${ }_{2}$ 18(2): 175-200.

İşler, D. B., Özdemir, Ş. (2010) "Hastane İşletmelerinde İçsel Pazarlama Yaklaşımının İş Tatmini ve Örgütsel Bağlılık Üzerine Etkisi: Isparta İli Örneği”, Hacettepe Sağlık İdaresi Dergisi, 13(2): 115142.

Kalaycı, Ş. (2005) "Faktör Analizi”, SPSS Uygulamalı Çok Değişkenli İstatistik Teknikleri, Editör: Kalaycı Ş., Ankara: Asil Yayın Dağıtım.

Karabağ Köse E. (2014) “Dezavantajlı Okullarda Öğretmenlerin Örgütsel Bağl1lıkları ile Örgütsel Sessizlik Arasındaki İlişkiler”, Uluslararası Türk Eğitim Bilimleri Dergisi, 2(2): 28-36.

Kayaoğlu, A.G. (2003) "Kitlenin Psikolojisi Ya Da Sosyal Psikolojinin 'Kitle'si: Kitlede Yeni Bir Anlayışa Doğru”, Kurgu Dergisi, 20: 205-218.

Kılıç, R., Keklik, B. ve Yıldız, H. (2014) “Dönüştürücü, Etkileşimci ve Tam Serbesti Tanıyan Liderlik Tarzlarının Örgütsel Sessizlik Üzerindeki Etkisini Belirlemeye Yönelik Bir Araştırma”, Yönetim ve Ekonomi 21(2): 249-268.

Koç, H. (2009) “Örgütsel Bağlılık ve Sadakat İlişkisi”, Elektronik Sosyal Bilimler Dergisi, 8(28): 200211.

Le Bon, G. (1997). “Kitleler Psikolojisi”, İstanbul: Hayat Yayınları.

Morrison E.W ve Milliken F.J. (2000) "Organizational Silence: A Barrier to Change and Development in a Pluralistic World", The Academy of Management Review, 25 (4): 706-725.

Mowday, R., Steers, R. ve Porter, L. (1982) "Employee-Organisation Linkages: The Psychology of Commitment", Absenteeism and Turnover, Londra: Academic Press.

Nakip, M., (2013) “Pazarlama Araştırmalarına Giriş: Veri Elde Etme, Örnekleme, Analizler”, Ankara: Seçkin Yayıncılık.

Neelam, N., Bhattacharya, S., Sinha, V. ve Tanksale, D. (2015) "Organizational Culture as a Determinant of Organizational Commitment: What Drives IT Employees in India?", Global Business and Organizational Excellence, 34 (2): 62-74.

Nikmaram S., Yamchi G.H., Shojaii S., Zahrani M.A., Alvani S.M. (2012) "Study On Relationship Between Organizational Silence And Commitment In Iran”, Work Applied Sciences Journal, 17(10): 1271-1277.

Öztürk, E., (2005) “Çoklu Doğrusal Regresyon Modeli”, SPSS Uygulamalı Çok Değişkenli İstatistik Teknikleri, Editör: Kalaycı Ş., Ankara: Asil Yayın Dağıtım. 
Özutku, H. (2008) “Örgüte Duygusal, Devamlı1ık ve Normatif Bağl1lık ile İş Performansı Arasındaki İlişkinin İncelenmesi”, İstanbul Üniversitesi İşletme Fakültesi Dergisi, 37 (2): 79-97.

Panahi, B., Veiseh, S., Divkhar, S. ve Kamari, F. (2012) “An Empirical Analysis on Influencing Factors on Organizational Silence and its Relationship with Employee's Organizational Commitment", Management Science Letters, 2(3): 735-744.

Pinder, C. C. and Harlos, K. P. (2001) 'Employee Silence: Quiescence and Acquiescence as Responses to Perceived Injustice'. In Rowland, K. M. and Ferris, G. R. (Eds), Research in Personnel and Human Resources Management, Vol. 20. New York: JAI Press, 331-69.

Sontag, S. (1969). "The Aesthetics of Silence”. In: S. Sontag (Ed.), Styles of Radical Will, NY. Farrar, Strauss \& Giroux. http://s3.amazonaws.com/academia.edu.documents/31003718/aesthetics-ofsilence-

sonntag3.pdf?AWSAccessKeyId=AKIAJ56TQJRTWSMTNPEA\&Expires=1439975485\&Signat ure=fiUk9wcnA6BQgcw4\%2BOTRfNfbHDU\%3D\&response-content-disposition=inline $(10.7 .2015)$.

TDK:

http://www.tdk.gov.tr/index.php?option=com gts\&arama=gts\&guid=TDK.GTS.557ab42bacac81 .62171450 (10.8.2015).

Usta, I. ve Küçükaltan, D. (2012) “Ödüllendirmenin Örgütsel Bağl1lığa Etkisi: İstanbul’daki Beş Yıldızlı Otel İşletmelerinde Bir Araştırma”. Ekonomi ve Yönetim Araştırmaları Dergisi, S. 1(2): 71-89.

Ülker, F. ve Kanten, P. (2009) Örgütlerde Sessizlik İklimi, İşgören Sessizliği ve Örgütsel Bağl1lık İlişkisine Yönelik Bir Araştırma, Aksaray Üniversitesi İ̈BF Dergisi, 1(2): 111-126

Vakola, M. ve Bouradas, D. (2005) “Antecedents and Consequences of Organizational Silence: An Emprical Investigation", Employee Relations, 27(5): 441-458.

Wiener, Y. (1982). "Commitment in Organizations: A Normative View", Academy of Management Review, 7(3), 418-428.

Yükselen, C. (2013) “Pazarlama Araştırmaları”, Ankara: Detay Yayıncılık. 